\title{
CYP2C19*2 polymorphism and clopidogrel resistance
}

\author{
CYP2C19*2 polimorfismo y resistencia a clopidogrel \\ Beuy Joob ${ }^{\text {* }}$ and Viroj Wiwanitkit ${ }^{2}$ \\ ${ }^{1}$ Sanitation Medical Academic Center, Bangkok, Thailand; ${ }^{2}$ Department of Tropical Medicine, Hainan Medical University, Hainan, China
}

Dear Editor,

We read the publication on the "Association of CYP2C19*2 polymorphism with clopidogrel resistance among patients with high cardiovascular risk in Northeastern Mexico" with a great interest ${ }^{1}$. Cedillo-Salazar et al. noted that "the presence of the CYP2C19*2 allele is related to resistance to the antiplatelet effect of CLO"1. Indeed, the CYP2C19*2 polymorphism can result in molecular change, and this can further result in alteration of phenotypic expression. However, there are also other genetic factors that might relate to clopidogrel resistance. The examples of genetic polymorphisms that might relate to clopidogrel resistance are CES1 gene and MDR1 polymorphisms ${ }^{2,3}$. Further, a study that addresses the effect of other possible confounding genetic polymorphisms is recommended.

\section{Conflicts of interest}

None.

\section{Funding}

The present investigation has not received any specific scholarship from the public, commercial, or non-profit agencies.

\section{Ethical disclosures}

Protection of human and animal subjects. The authors declare that no experiments were performed on humans or animals for this study.

Confidentiality of data. The authors declare that no patient data appear in this article.

Right to privacy and informed consent. The authors declare that no patient data appear in this article.

\section{References}

1. Cedillo-Salazar FR, Martínez-Jacobo L, Pérez-Páramo YX, Cerda-Flores R, Martínez LE, Jaime-Pérez JC, et al. Association of CYP2C19*2 polymorphism with clopidogrel resistance among patients with high cardiovascular risk in Northeastern Mexico. Arch Cardiol Mex. 2019;89:324-9.

2. Mirzaev KB, Osipova DV, Kitaeva EJ, Shprakh VV, Abdullaev SP Andreev DA, et al. Effects of the rs2244613 polymorphism of the CES1 gene on the antiplatelet effect of the receptor P2Y12 blocker clopidogrel. Drug Metab Pers Ther. 2019;1-8.

3. Al-Husein BA, Al-Azzam SI, Alzoubi KH, Khabour OF, Nusair MB, Alzayadeen $S$. Investigating the effect of demographics, clinical characteristics, and polymorphism of MDR-1, CYP1A2, CYP3A4, and CYP3A5 on clopidogrel resistance. J Cardiovasc Pharmacol. 2018;72:296-302. 